\title{
Article/Artigo
}

\section{Epidemiologic aspects of toxoplasmosis and evaluation of its seroprevalence in pregnant women}

\author{
Aspectos epidemiológicos da toxoplasmose e avaliação de sua soroprevalência em gestantes
}

\author{
Amanda Luiza Fonseca ${ }^{1}$, Reysla Andrade Silva ${ }^{1}$, Blima Fux $^{2}$, Ana Paula Madureira ${ }^{3}$, Fabrizio Furtado de Sousa ${ }^{4}$ \\ and Carina Margonari ${ }^{5,6}$
}

\begin{abstract}
Introduction: The aim of the present study was to analyze the exposure to risk factors for toxoplasmosis disease and the level of knowledge in pregnant women who were treated by the Public Health Care System (SUS) from October 2007 to September 2008 in Divinópolis City, Brazil. Methods: We analyzed 2,136 prenatal exams of pregnant women that were treated from October 2007 to September 2008. Results: Out of the 2,136 pregnant women evaluated, 200 answered a quantitative questionnaire; $49.5 \%$ were seropositive for immunoglobulin (Ig) G and $3.6 \%$ for IgM. Comparative analysis of congenital toxoplasmosis cases were evaluated in 11 regions and showed an irregular distribution $(\mathrm{p}<0.01)$. This difference was also observed among the pregnant women observed in each location. The results from the questionnaire show that $93 \%$ of the pregnant women had no knowledge about toxoplasmosis, and $24 \%$ presented with positive serology, but no clinical manifestation. Analysis for pregnant IgG-positive women and the presence of pets showed a statistically significant correlation $(\mathrm{p}<0.05)$, suggesting that the transmission of this disease might occur in the domestic environment. Conclusions: We suggest the implementation of a triage program for pregnant women and health education to encourage their use of SUS services.
\end{abstract}

Keywords: Toxoplasmosis. Epidemiology. Toxoplasma gondii. Congenital infection.

\section{RESUMO}

Introdução: $\mathrm{O}$ objetivo deste trabalho foi estudar os fatores de riscos da toxoplasmose e investigar o nível de conhecimento das gestantes atendidas pelo Sistema Único de Saúde (SUS), no município de Divinópolis, Brasil. Métodos: Para isso, foram analisados os exames pré-natais de 2.136 gestantes durante o período de outubro de 2007 a setembro de 2008. Resultados: Das 2.136 gestantes avaliadas, 200 foram entrevistadas; destas, $49,5 \%$ foram soropositivas para $\operatorname{IgG~e~3,6\% ~para~IgM.~A~análise~comparativa~dos~casos~de~toxoplasmose~congênita,~entre~as~} 11$ regiões que compõem o município, demonstrou uma distribuição irregular da enfermidade entre as localidades $(\mathrm{p}<0,01)$. As respostas dos questionários demonstraram que $93 \%$ das gestantes conhecem quase nada sobre toxoplasmose sendo que $24 \%$ apresentaram sorologia positiva sem manifestações clínicas. A análise de correlação entre gestantes IgG positivas e presença de animais de estimação foi estatisticamente significativa $(p<0,05)$, reforçando a possibilidade da transmissão da enfermidade ocorrer no ambiente doméstico. Conclusões: É sugerida a implementação de um programa de triagem das gestantes, Educação em Saúde, que amplie e estimule a utilização dos serviços prestados pelo SUS.

Palavras-chaves: Toxoplasmose. Epidemiologia. Toxoplasma gondii. Infecção congênita.

1. Curso de Ciências Biológicas, Fundação Educacional de Divinópolis, Universidade Estadual de Minas Gerais, Divinópolis, MG. 2. Departamento de Patologia, Universidade Federal do Espírito Santo, Vitória, ES. 3. Departamento de Parasitologia, Universidade Federal de São João Del Rey, São João Del Rey, MG. 4. Instituto de Ensino Superior e Pesquisa, Fundação Educacional de Divinópolis, Universidade Estadual de Minas Gerais, Divinópolis, MG. 5. Laboratório de Educação em Saúde e Ambiente, Centro de Pesquisas René Rachou, Fundação Oswaldo Cruz, Belo Horizonte, Minas Gerais. 6. Núcleo de Saúde Coletiva, Fundação Educacional de Divinópolis, Universidade Estadual de Minas Gerais, Belo Horizonte, MG. Address to: Dra. Carina Margonari. Laboratório de Educação em Saúde e Ambiente/CPqRR/FIOCRUZ. Av. Augusto de Lima 1715, Barro Preto, 30190-002 Belo Horizonte, MG, Brasil.

Phone: 5531 3349-7817

e-mail: margonari@cpqrr.fiocruz.br

Received in 18/05/2011

Accepted in 30/09/2011

\section{INTRODUCTION}

Toxoplasmosis is found in almost every country, of various climates and social conditions, with variable levels in the percentage of positive tests. For example, the prevalence of toxoplasmosis in women of reproductive age in a suburban community of Maracaibo, Venezuela, was $33 \%^{1}$, $12.3 \%$ in China $^{2}, 27.9 \%$ in the Palestine ${ }^{3}, 47 \%$ in France ${ }^{4}, 48.6 \%$ in Albania ${ }^{5}$, and $57.6 \%$ in Egypt ${ }^{6}$. In Brazil, the seroprevalence was determined to be $50-80 \%$; in Sergipe, its prevalence was $69.3 \%^{7}$; in the indigenous populations of Iauareté, São Gabriel da Cachoeira, Amazonas, it was $73.5 \%{ }^{8}$; and in Alagoas, it was $43.9 \%{ }^{9}$. This is a challenging public health situation with respect to planning and devising a triage strategy for this disease in a practical and comprehensive manner that would improve the treatment of affected pregnant women. These measures would contribute to a reduction in the morbidity/mortality of the mother and fetus, and thus improve health indicators ${ }^{10-12}$.

Toxoplasmosis is diagnosed indirectly using serological methods, and directly by polymerase chain reaction (PCR), hybridization, isolation, histology, and other methods ${ }^{13}$. Serological diagnosis is performed by the detection of immunoglobulins A, G, and M (IgA, IgG, and IgM, respectively) produced against the parasite by using several methods. Although enzyme-linked immunosorbent assays are the most commonly used tests, the dye test is considered the gold standard for toxoplasmosis diagnosis ${ }^{13}$.

Some congenital toxoplasmosis studies showed significant differences between the rate of positive diagnosis and the socioeconomic status of some Brazilian regions ${ }^{14,15}$. In addition, it has been observed that some eating habits increase the rate of Toxoplasma gondii transmission.

Recently, it was observed that aspects associated with urban cleaning services and personal hygiene are important factors in the dissemination of toxoplasmosis. Elsheika observed that age group, 
number of visits to foreign countries, and the habit of ingesting beverages prepared with untreated water can increase the risk of contracting toxoplasmosis ${ }^{16}$. In addition, the level of education, income level, the presence of cats at home, and the habit of eating vegetables are factors associated with a higher chance of $T$. gondii infection ${ }^{17}$. Innes and Dabritz \& Conrad used epidemiological surveys to emphasize the importance of the cat in the transmission of toxoplasmosis to intermediary hosts ${ }^{18,19}$.

Tropical diseases continue to affect thousands of Brazilians due to the lack of urban planning (poor sanitation conditions), deficient or absent sanitation compliance surveillance, inadequate health policy, poor hygiene habits, and lack of awareness of the population and health professionals ${ }^{20,21}$. In Divinópolis City, State of Minas Gerais, no data are available on toxoplasmosis at the Centro de Saúde Coletiva-Vigilância Epidemiológica. Therefore, the present study aimed to analyze the incidence of toxoplasmosis and the main factors that contribute to the maintenance and dissemination of this disease, and to collaborate in the design of prophylactic measures based on the real situation in Divinópolis.

It is important to integrate and optimize the services offered to pregnant women by different health professionals. A lack of a consensus and fragmented services hinder the characterization of the risks during gestation and the monitoring of prenatal exams by a team of health professionals. This influences, above all, the ability to monitor the health status of the child exposed to the possible vertical transmission of the disease $\mathrm{e}^{22-24}$.

\section{METHODS}

\section{Characterization of the population}

The City of Divinópolis, with 213,076 inhabitants ${ }^{25}$, is located in the mid-western region of Minas Gerais, at $100 \mathrm{~km}$ from Belo Horizonte. Of its $709-\mathrm{km}^{2}$ area, $524 \mathrm{~km}^{2}$ is rural, and, because of its location, economic development, and organization of its health care system, it is a macroregional center for 54 neighboring cities. It is considered a medium-sized city, and its economy is based on heavy industry, mainly steel mills.

According to the Database of the Public Health Care System (DATASUS), the main population age group is 20-49 years; women represent the majority of the population.

The urban structure of the city is composed of a relatively small city center compared to a rather large suburban area with several small neighborhoods, several of which lack basic infrastructure, i.e., the streets are unpaved and basic sanitation and parks are absent. Public transportation serves all neighborhoods but is unsafe because of the poor condition of the roads. DATASUS data from 2000 show that $16 \%$ of the sewage is collected in rudimentary septic tanks ${ }^{26}$.

\section{Sample}

The sample consisted of the results of toxoplasmosis serological exams from pregnant women that were treated at SUS from October 2007 to September 2008.

The data were provided by the Municipal Health Center, where all of the tests performed by SUS, including toxoplasmosis tests, are archived. The data were analyzed as follows: I) all toxoplasmosis tests performed in pregnant women in the sample period were investigated, and II) from these positive results, we selected patients with acute phase and chronic toxoplasmosis disease. The tests were performed using blood samples from the pregnant women.
The addresses of the seropositive pregnant women were filed and used in the comparative analysis of toxoplasmosis cases between the 11 administrative regions of the city.

\section{Climate data collection}

The positive test results from the acute disease phase were correlated with climate data with the intent to observe the characteristics of toxoplasmosis in varying environments. The incidence of the disease declines during summer because the heat can render the oocytes in the environment non-viable ${ }^{27}$. On the basis of this study, climate data (highest temperature, lowest temperature, precipitation, and relative humidity) were collected daily from the site http://tempoagora.uol. com.br/previsaodotempo.html/brasil/Divinopolis-MG. At the end of each month, the average maximum and minimum temperatures, precipitation, and relative humidity were calculated for comparison with the data for the acute cases of the disease in Divinópolis ${ }^{28}$.

\section{Survey and interview}

Two clinics (Health Unit Niterói (PSN) and Urban Center Social (CSU)) were chosen, for convenience, as a second approach, i.e., the collection of an epidemiological questionnaire from pregnant women treated during the period of the development of this study. One hundred pregnant women aged $>18$ years were interviewed in each clinic.

The epidemiological questionnaire was formulated according to similar published research ${ }^{29-31}$. The analysis of the collected data had the intent of accessing the level of awareness of the interviewed women and their risk of infection.

The project was submitted to and approved by the Ethics Committee of the Municipal Health/CEP-SEMUSA and by the Ethics committee of the Hospital São João de Deus/CEP-HSJD (protocol number 000035).

\section{Statistical analysis}

We calculated the prevalence and frequency of the data and used the chi-square test for analysis using the software Statistical Analysis System (SAS).

\section{Ethical considerations}

The project was approved by the Ethics Committee in Research of the Hospital São João de Deus in Divinópolis City, State of Minas Gerais on November 26, 2007 (register 000035, no. 33/2007). All of the participants were informed about the objectives of the present study. Their participation was permitted only after signature of the Term of Free and Clarified Assent. The present study was developed in accordance with the ethical principles of the Declaration of Helsinki (1964, reformulated in 1975, 1983, 1989, 1996, 2000, and 2008) of the World Medical Association, and follows the rules of the Committee of Ethics in Research of the Hospital São João de Deus.

\section{RESULTS}

\section{Data collection}

The test results from 2,136 pregnant women from October 2007 to September 2008 were filed. There were a high number of IgGpositive test results for toxoplasmosis (49\%). This percentage of positive results was constant throughout the study period (Table 1). The number of pregnant women positive for IgM acute toxoplasmosis was lower than the total number of IgG-positive women. 
TABLE 1 - Data collected from pregnant women at the Municipal Health Center (CEMAS), who underwent toxoplasmosis testing between October 2007 and September 2008. Data have been provided for acute and chronic cases in Divinópolis City, State of Minas Gerais, Brazil.

\begin{tabular}{|c|c|c|c|c|c|}
\hline Acute and chronic toxoplasmosis in pregnant women & Total & IgG-positive & Percentage & IgM-positive & Percentage \\
\hline October & 225 & 115 & 51.1 & 4 & 1.8 \\
\hline November & 183 & 103 & 56.3 & 6 & 3.3 \\
\hline December & 182 & 91 & 50.0 & 6 & 3.3 \\
\hline January & 198 & 79 & 39.9 & 3 & 1.5 \\
\hline February & 163 & 80 & 49.1 & 5 & 3.1 \\
\hline March & 105 & 58 & 55.2 & 3 & 2.9 \\
\hline April & 202 & 90 & 44.6 & 5 & 2.5 \\
\hline May & 192 & 101 & 52.6 & 10 & 5.2 \\
\hline June & 188 & 95 & 50.5 & 9 & 4.8 \\
\hline July & 185 & 87 & 47.0 & 11 & 6.0 \\
\hline August & 162 & 77 & 47.5 & 5 & 3.1 \\
\hline September & 151 & 81 & 53.5 & 10 & 6.6 \\
\hline Total & 2,136 & 1,057 & 49.5 & 77 & 3.6 \\
\hline
\end{tabular}

IgG: immunoglobulin G; IgM: immunoglobulin M.

A subtle increase in the number of toxoplasmosis cases was observed in the 25-29-years age group and women aged $>30$ years, with 513 and 529 tested women in each respective age group; $3.8 \%$ tested positive in both age groups. This difference is not statistically significant. This indicates that toxoplasmosis cases are distributed in all age groups, and confirms that the disease affects people of all ages, and only depends on exposure to the parasite (Table 2).

We performed a comparative study of the toxoplasmosis cases between the 11 regions that comprise the city. The Kruskal-Wallis test $(\mathrm{p}<0.01)$ revealed a significant difference in the number of IgG- and IgM-positive pregnant women in the different regions. However, there was also a statistically significant difference between the total number of women that underwent testing in the different regions (Table 3).

A monthly comparison of the number of positive women for acute toxoplasmosis and the climate data collected in the same period did not indicate any significant differences; we only observed a trend for an increase in the number of toxoplasmosis cases in the post rainy season (May-September 2008) (Figure 1).
TABLE 2 - Number of pregnant women positive for acute toxoplasmosis, by age group, between October 2007 and September 2008, in Divinópolis City, State of Minas Gerais, Brazil.

\begin{tabular}{lccc}
\hline & \multicolumn{2}{c}{ Seropositive pregnant women and age } \\
\cline { 2 - 4 } Age group (years) & $\begin{array}{c}\text { Pregnant women } \\
\text { analyzed }\end{array}$ & $\begin{array}{c}\text { IgG-positive } \\
\text { pregnant women }\end{array}$ & $\begin{array}{c}\text { IgM-positive } \\
\text { pregnant women }\end{array}$ \\
\hline$\leq 14$ & $\mathbf{n}$ & $\mathbf{n}$ & $\mathbf{n}$ \\
$15-19$ & 377 & 148 & 0 \\
$20-24$ & 536 & 245 & 11 \\
$25-29$ & 513 & 268 & 16 \\
$\geq 30$ & 529 & 296 & 20 \\
ID & 163 & 93 & 20 \\
\hline Total & $\mathbf{2 , 1 3 6}$ & $\mathbf{1 , 0 5 8}$ & 10 \\
\hline
\end{tabular}

IgG: immunoglobulin G; IgM: immunoglobulin M; n: number; ID: not identified.

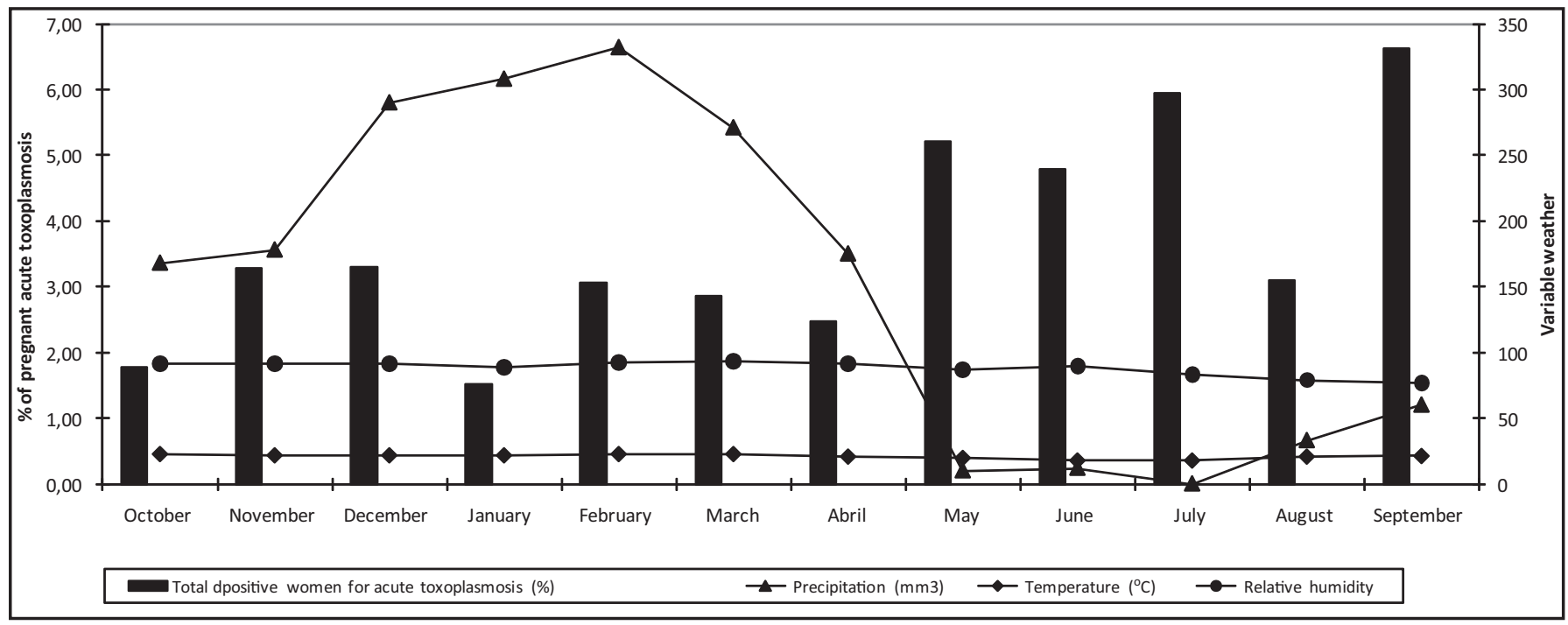

FIGURE 1 - Correlation between the number of pregnant women positive for acute toxoplasmosis and precipitation, average temperature, and relative humidity, in Divinópolis City, State of Minas Gerais, Brazil. 
TABLE 3 - Number of pregnant women positive for toxoplasmosis per administrative area of Divinópolis City, State of Minas Gerais, Brazil, between October 2007 and September 2008.

\begin{tabular}{|c|c|c|c|c|c|}
\hline \multirow[b]{3}{*}{ Region } & \multicolumn{5}{|c|}{ Seropositive pregnant women and regions } \\
\hline & \multirow{2}{*}{$\begin{array}{c}\text { Pregnant } \\
\text { women } \\
\text { analyzed } \\
\mathbf{n}\end{array}$} & \multicolumn{2}{|c|}{$\begin{array}{l}\text { Pregnant women } \\
\text { positive for } \\
\text { toxoplasmosis-IgG test }\end{array}$} & \multicolumn{2}{|c|}{$\begin{array}{c}\text { Pregnant women } \\
\text { positive for acute } \\
\text { toxoplasmosis-IgM test }\end{array}$} \\
\hline & & $\mathbf{n}$ & $\%$ & $\mathbf{n}$ & $\%$ \\
\hline 1 & 272 & 115 & 42.3 & 8 & 2.9 \\
\hline 2 & 399 & 190 & 47.6 & 11 & 2.7 \\
\hline 3 & 227 & 135 & 59.5 & 11 & 4.8 \\
\hline 4 & 203 & 87 & 42.8 & 1 & 0.5 \\
\hline 5 & 376 & 179 & 47.6 & 16 & 4.2 \\
\hline 6 & 186 & 99 & 53.2 & 6 & 3.2 \\
\hline 7 & 84 & 32 & 38.1 & 2 & 2.4 \\
\hline 8 & 16 & 7 & 43.7 & 1 & 6.2 \\
\hline 9 & 58 & 36 & 62.1 & 6 & 10.3 \\
\hline 10 & 34 & 19 & 57.1 & 0 & 0.0 \\
\hline 11 & 14 & 8 & 56.2 & 1 & 7.1 \\
\hline $\mathrm{X}^{*}$ & 267 & 150 & 56.5 & 14 & 5.2 \\
\hline Total & 2,136 & 1,057 & 49.5 & 77 & 3.6 \\
\hline
\end{tabular}

IgG: immunoglobulin G; IgM: immunoglobulin M; n: number. *Divinópolis neighborhood cities.

\section{Epidemiological questionnaire}

At the PSN, 10 pregnant women were interviewed per day, while 6 were interviewed per day at the CSU. However, because the questionnaire was only answered once by each pregnant woman during the research period, there was at least 1 woman who had already been interviewed at all times. Because prenatal care is given throughout the gestational period, the average number of questionnaires answered during the visiting days was altered.

The data from the questionnaire from both health units showed that most of the surveyed women were aged between 18-27 years. Only $2 \%$ of them lived in rural areas, $56 \%$ of all women surveyed had 1 child, $32 \%$ had 2 children, $7 \%$ had 3 children, and $5 \%$ had 4 children. Most of the interviewed women (35.5\%) did not complete high school.

As for the presence of cats in the residence, $9 \%$ of the interviewed women had cats as pets. Of these, $\sim 90 \%$ had 1 or 2 cats; $95 \%$ of the cats defecated in litter boxes or in the backyard, and $77 \%$ of the women interviewed collected their cat's feces.

For eating habits, $14.5 \%$ of women consumed undercooked meat, $17.5 \%$ drank uncooked milk, $98 \%$ stated that they washed vegetables before consumption, and $73 \%$ consumed some kind of handmade food.

Of the women interviewed, 98\% lived in homes with basic sanitation (sewage collection and treated water); however, 63.5\% had noticed the presence of rodents in or around their homes.

Most of the women (93\%) had little or no knowledge about toxoplasmosis (Figure 2). Despite this, 3\% stated that they had had toxoplasmosis, whereas $20 \%$ did not know how to answer.

All 200 women interviewed underwent a serological diagnostic test for toxoplasmosis. Of these, 48 were IgG-positive (24\%) and none were in the acute phase of the disease.

When the questionnaires from the 2 health units (PSN and CSU) were analyzed separately, it was observed that $10 \%$ and $8 \%$ of the interviewees, respectively, had cats for pets. For eating habits, 39\% and $36 \%$ had direct contact with soil, $19 \%$ and $10 \%$ ate undercooked meat habitually, $23 \%$ and $12 \%$ drank uncooked milk, $97 \%$ and $99 \%$ washed vegetables before consumption, $94 \%$ and $91 \%$ used treated water to wash food items, and $99 \%$ and $96 \%$ drank filtered or treated water, respectively.

Although $99 \%$ of the interviewees at PSN and 98\% of those at CSU lived in homes with basic sanitation, 65\% (PSN) and 62\% (CSU) of them had observed the presence of rodents in or around their homes.

At PSN, $3 \%$ of the women, compared to $2 \%$ at CSU, stated that they had had clinical symptoms of toxoplasmosis. However, in both clinics, $78 \%$ of the interviewees had no knowledge about the disease.

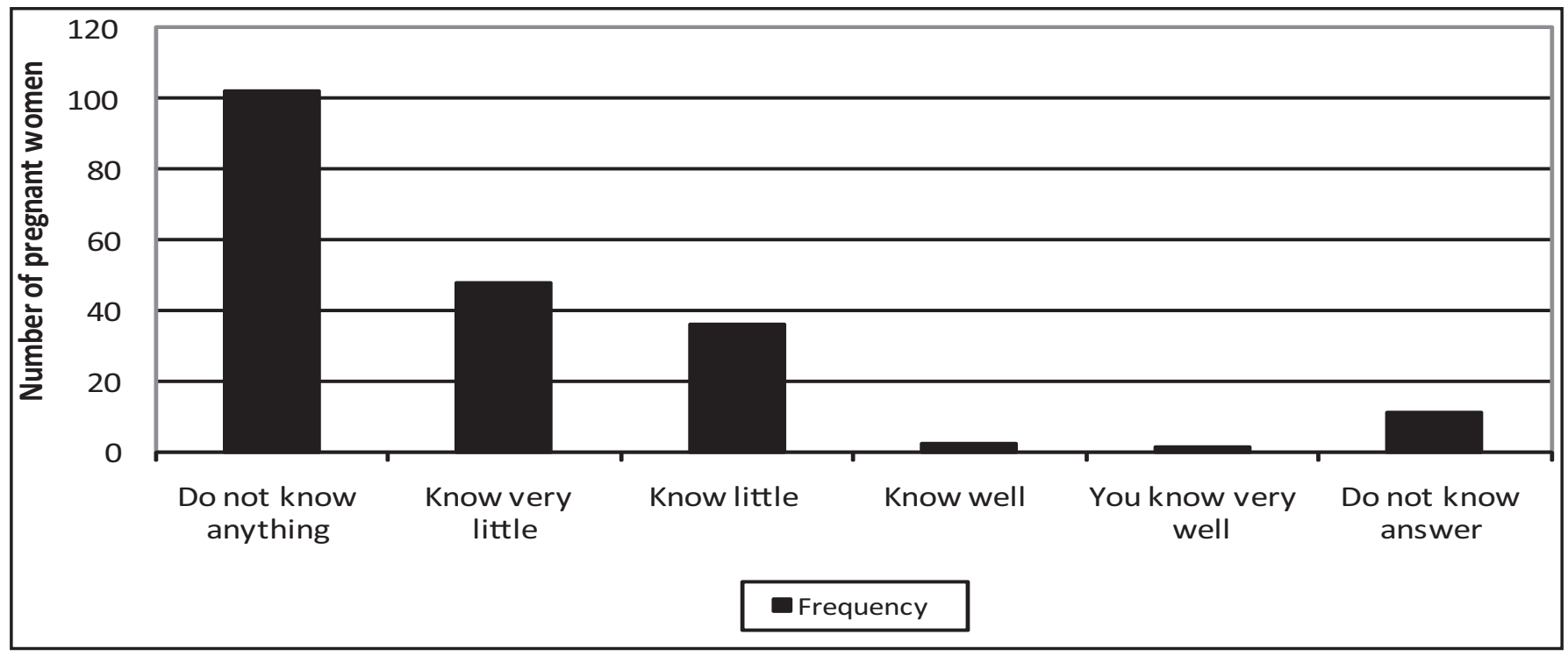

FIGURE 2 - Level of knowledge in pregnant women with toxoplasmosis treated at both health clinics in Divinópolis City, Brazil. 


\section{DIscussion}

Toxoplasmosis is a zoonosis caused by a protozoan that infects many vertebrates, including man. It is a widespread infectious disease in Brazil and worldwide, although the prevalence and incidence of the disease in different regions are influenced by local characteristics, such as environmental factors, eating habits, culture, age, among others. This was demonstrated using the prevalence of the disease in pregnant women from different geographic locations, climates, and eating habits ${ }^{32}$.

The results from the present study provide evidence that $49.5 \%$ of the analyzed pregnant women were infected and in the chronic phase of the disease. Similar results were found in other regions of Brazil, e.g., $69.3 \%$ in Sergipe ${ }^{6}, 73.5 \%$ in the indigenous Amazonas population $^{9}$, and $59.8 \%$ in Porto Alegre ${ }^{33}$.

The comparison of the seropositivity of the pregnant women in Divinópolis with the prevalence of toxoplasmosis in other countries showed that the number of cases found in this study is twice that diagnosed in the Palestine $(27.9 \%)^{6}, 4$ times higher than in China $(12.3 \%)^{2}$, and also higher than in Venezuela $(33 \%)^{1}$. In contrast, the numbers found were similar to the prevalence found in rural populations of France $(47 \%)^{4}$, Albania $(48.6 \%)^{5}$, and rural $(57.6 \%)$ and urban $(46.5 \%)$ areas of Egypt ${ }^{6}$. The high prevalence of toxoplasmosis encountered in Brazil and in the world is explained by several factors, such as the lack of preventive measures in basic health care, educational programs aiming to increase awareness about the disease, and monitoring of the population of pregnant women.

In this study, 2,136 toxoplasmosis tests were analyzed, 1,057 (49.5\%) had positive serology, showing that half of the women evaluated have the chronic form of the disease or were exposed to T. gondii. Of the $1,057 \mathrm{IgG}$-positive cases, 77 were also IgM-positive, i.e., in the acute phase of the disease (Table 1). The number of cases in the acute phase varied from 3-6 cases per month from October 2007 to April 2008. From May to September 2008, an increase in the number of cases was observed with 9-11 cases per month. These data are statistically significant by the Kolmogorov-Smirnov $(\mathrm{p}<0.01)$ and KruskalWallis $(\mathrm{p}<0.01)$ tests. Chronic cases are observed in all months and all regions analyzed. The acute cases were also observed in all months, but with a higher rate in May, July, and September.

Despite the large sample size of the study, it was not possible to identify discrete foci of toxoplasmosis in Divinópolis City because there are significant differences in the number of cases analyzed by region. It also demonstrates that the populations in the different regions behave differently. In regions 7, 8, 9, and 10), pregnant women seek public health care services less frequently than in the other regions. Whereas in regions $1,2,3,4,5$, and 6 , these services are used more often than in the other regions (Table 3). This difference may be due to a lack of information about the services offered by SUS, or the lack of an SUS clinic close to the residence. Regions 8 and 10 comprise more than 25 neighborhoods; however, they are served by only 1 or 2 SUS units. Region 7 is very close to region 1 , and this causes a migration of patients to the central region.

Foulon ${ }^{35}$ proposed that a toxoplasmosis serological status survey during pregnancy should be combined with a preventive program, depending on the importance of congenital toxoplasmosis as a public health issue. In countries where the prevalence is low during pregnancy, because of low susceptibility and the small number of patients at risk of seroconversion and fetal infection, serological monitoring is not recommended as it is expensive ${ }^{34}$. In countries where the prevalence is high during pregnancy, serological monitoring of toxoplasmosis is important to reduce the incidence of congenital infections.

Nonetheless, analysis of the data from a 12-month period showed the need to increase awareness in the population (especially for pregnant women) about the importance of prenatal care; the need for incentives to seek medical assistance at public health care centers (in some regions, assistance at health centers is sought less frequently); and the need for educational material to allow the population, pregnant women, and health professionals to gain access to information about the main diseases afflicting the local population.

The epidemiological questionnaire was given randomly to 78 pregnant women aged 18-23 years, 80 pregnant women aged 24-29 years, 31 pregnant women aged $30-35$ years, and 11 pregnant women aged 36-40 years, totaling 200 surveys between the 2 health centers (PSN and CSU). Of these respondents, only $2 \%$ resided in the rural area of the city.

Of the 200 interviewed women, 48 (24\%) were IgG-positive and none were in the acute phase of the disease. However, during the interview, when asked if they had ever been exposed to T. gondii, $20 \%$ did not know how to respond, and 3\% answered that they had had toxoplasmosis and demonstrated better knowledge of the disease. Furthermore, 93\% of the interviewees showed little (32\%) or no knowledge about the basic concepts of the disease (68\%), and 92.5\% did not have a college degree. These data are in agreement with the current literature. According to Carellos et al., the higher the educational level, the better awareness of pregnant women about toxoplasmosis and other diseases ${ }^{12}$. They also observed a correlation $(\mathrm{p}=0.0455)$ between IgG-positive pregnant women and the presence of pets in the house. Some observed factors increase the risk of toxoplasmosis transmission, e.g., presence of rodents and cats in or around the residence, direct contact with soil, and the habit of eating undercooked meat. Other studies showed that $60 \%$ of interviewed women did not receive information about contamination risks by their prenatal care health professionals ${ }^{12}$. Therefore, the authors conclude that the inadequate application of the prenatal toxoplasmosis triage protocol used in this study can generate a financial burden without improving the quality of prenatal health care.

With respect to the presence of pets in the house, it was observed that $77 \%$ of the pregnant women that had cats were responsible for collecting the animal's feces on a daily basis. This is of concern as toxoplasmosis transmission can occur by the ingestion of oocytes present in the soil ${ }^{35}$. Pregnant women must avoid eating undercooked meat, wash their hands after handling raw meat, avoid drinking unfiltered water and unpasteurized milk, as well as foods exposed to flies, cockroaches, ants, and other insects. Fruits and vegetables should be well washed, and contact with cats and soil should be avoided, or at least gloves should be worn while gardening, handling materials potentially contaminated with cat feces, or the cat litter box ${ }^{32}$.

Although $98 \%$ of the pregnant women lived in houses with basic sanitation, we believe that an improvement is needed in the system because $60 \%$ of them observed the presence of rodents near their residence. This can contribute to the dissemination of the disease as rodents have been found to be naturally infected with $T$. gondii ${ }^{36}$. It is known that rodents are synanthropic, i.e., they can live in the wild or in and around our homes; therefore the presence of infected rodents 
in residences increases the risk of domestic cat infection (as cats can feed on rodents), consequently increasing the risk of infection of other animals, including man. A curious fact observed by Vyas et al. was that the infection of rats by $T$. gondii inhibits their aversion to the smell of cat urine ${ }^{37}$. The postulated hypothesis in this case was that the parasite modifies the host's behavior in order to increase its chances of transmission, as although the parasite can infect rats it only goes through sexual reproduction in the intestines of felines. This facilitates an encounter with an infected rodent in houses where a domestic cat is present, increasing the chances of infection.

Of the pregnant women interviewed, 39\% (PSN) and 36\% (CSU) had direct contact with soil, which can increase the chance of contact with oocytes. Recently, the distribution of T. gondii in soil was studied in relation to cat feces in urban areas. The results showed that a high concentration of oocytes can be detected in soil using molecular methods; moreover, they suggested that the distribution of contaminated areas is highly heterogeneous. Positive samples were only found in the locations used by cats to defecate, which means that the higher risk areas for human and animal infection can be localized and controlled ${ }^{38}$.

The habit of eating undercooked meat was observed in 19\% (PSN) and 10\% (CSU) of the pregnant women interviewed. This also increases the chances of an acute infection. Zou et al. observed that infection by T. gondii in swine is widespread (22.3\%), and undercooked meat is a risk factor for toxoplasmosis transmission ${ }^{39}$.

High rates of T.gondii-contaminated swine meat were found in several Brazilian regions. Millar et al. observed a seroprevalence of $25.5 \%{ }^{40}$. In Erechim, southern Brazil, Belfort-Neto et al. collected samples of tongue and pig diaphragm and observed high rates of infection and the presence of genotypes not frequently reported in previous studies ${ }^{41}$. Millar et al. studied the infection risk of swine packing plant workers in Palmas, State of Parana, Brazil ${ }^{42}$. They found that handling carcass infected with tissue cysts may have contributed to transmission as a risk factor, as well as contact with contaminated soil or cats. In the State of Parana, contaminated fresh sausages were found ${ }^{43}$. Moreover Garcia et al. found antibodies to T. gondii in chickens in the City of Jaguapitã, State of Paraná, Brazil ${ }^{44}$. In the State of Pernambuco, 35.3\% of lambs and $40.4 \%$ of goats were positive for toxoplasmosis ${ }^{45}$. A similar study in São Paulo showed that $14.5 \%$ of goats tested positive ${ }^{46}$. Therefore, handlers and meat consumers should be alerted to the risk of $T$. gondii contamination via this product. Hygiene and prevention guidelines should be given to minimize the risk of infection in these individuals. These data demonstrate that the habit of consuming undercooked meat is an important factor in the transmission and dissemination of toxoplasmosis.

Drinking raw milk is also an important factor in toxoplasmosis dissemination; however, 23\% (PSN) and 12\% (CSU) of the pregnant women interviewed in this study had this habit. Hiramoto et al. confirmed the infectivity and resistance of T. gondii cysts in milk and homemade cheese ${ }^{47}$. To test this, homemade cheese was made using infected milk and administered to groups of mice. Infection was detected by the presence of brain cysts in infected mice that presented with positive serological and histological tests after 5 weeks. The infectivity of the cysts of T. gondii strain ME-49 was maintained in the milk even after storage of up to 20 days at $4^{\circ} \mathrm{C}$. The cysts were also resistant to the cheese fabrication process, and were infectious for up to 10 days. These findings show that milk and dairy products might be important as a source of human infection by $T$. gondii, highlighting the importance of the pasteurization of milk before consumption or processing.
The results of the present study also show that the older the pregnant women were, the more children they had, and the more children they had, the least time they had to clean up their cats' feces. This behavior enables the maturation of oocytes in the environment, facilitating toxoplasmosis transmission to the whole family. As a preventive method, the collection and incineration of cat feces should be performed daily.

Triage programs for pregnant women should be implemented and are of great importance, especially in public hospitals, where there is a higher prevalence of toxoplasmosis compared to private hospitals ${ }^{48}$. Souza et al., in a study of blood samples from 80 female students aged between 18-35 years, observed that 53 (66.2\%) students were susceptible to toxoplasmosis during a possible pregnancy $^{49}$. In addition, $33.8 \%$ of the students were seropositive. This demonstrates the importance of prenatal care and providing the necessary information to pregnant women as well as to the population susceptible to the disease.

The lack of information about toxoplasmosis was clearly the most relevant factor, and this influences directly the transmission and dissemination of the disease. Therefore, awareness campaigns should be conducted in Divinópolis City. In addition, a triage program for pregnant women that stimulates the usage of the health services at their local health clinics should also be implemented. These initiatives might be designed with the reality of the city and studies of other locals in mind. According to Margonato et al., existing prenatal triage programs for toxoplasmosis need to be revised, especially the prophylactic guidelines given to pregnant women ${ }^{11}$. Conversely, Castilho-Pelloso et al. pointed out the existence of pregnant women suspected of toxoplasmosis that was not being investigated and fetuses without adequate monitoring ${ }^{50}$. The authors' evidence that fundamental aspects of prenatal care are not observed systematically highlight the need to implement a surveillance system for pregnant women and children exposed to T. gondii.

In addition, lack of information about the disease can contribute to the maintenance of the disease in a city, Therefore, the implementation of adequate educational programs, improvement in sanitation, and a surveillance policy to avoid an increase in toxoplasmosis cases are needed. Andrade et al. highlighted the need for preventive education at the beginning of prenatal care, including monitoring of ocular symptoms, irrespective of whether the patients are susceptible or not ${ }^{51}$.

Education is not a simple task, especially in health, as it is not limited to the communication of information to the population for the care of themselves and their family. Indeed, it is a shared practice of knowledge exchange that needs to be developed for daily life in health work. For this, it is necessary to promote an educational practice that aims for the participation of health service users, directing this work according to their needs, beliefs, and life history, making them co-producers of the educational process with the health professionals.

Health education is an important form of prevention; thus, integration it necessary among the health service departments, giving the population adequate care. As information regarding toxoplasmosis is not well disseminated, it is of extreme importance that different methods of education are used, such as seminars, meetings, and conferences on toxoplasmosis, for all of the agents involved in health services, as well as the population in general. Pamphlets, role play, games, and theater should be used to inform 
the population and at the same time highlight the importance of the disease and its prevention. The implemented programs can not only protect the population but can also reduce the financial expenditure on the treatment of patients affected by the disease. This makes health education a great ally to the population and health care profession, and should be widely used.

\section{ACKNOWLEDGMENTS}

To the Scientific Initiation students, volunteers, and Biological Science students, the workers at the Health Unit Niterói, the Urban Social Center, the Hospital São João de Deus, the City Hall of Divinópolis and the pregnant women who contributed to the realization of this study.

\section{CONFLICT OF INTEREST}

The authors declare that there is no conflict of interest.

\section{FINANCIAL SUPPORT}

Divinópolis Educational Foundation/University of Minas Gerais/Institutional Program for Research Support-FUNED/ UEMG/PAPq (announcement 05/2007) and the Research Support Foundation of Minas Gerais- FAPEMIG (announcement 5.87/08) for funding.

\section{REFERENCES}

1. Diaz-Suárez O, Estevez J. Seroepidemiology of toxoplasmosis in women of childbearing age from a marginal community of Maracaibo, Venezuela. Rev Inst Med Trop 2009; 51:13-17.

2. Xiao Y, Yin J, Jiang N, Xiang M, Hao L, Lu H, et al. Seroepidemiology of human Toxoplasma gondii infection in China. BMC Infect Dis 2010; 10:4

3. Nijem KI, Al-Amleh S. Seroprevalence and associated risk factors of toxoplasmosis in pregnant women in Hebron district, Palestine. East Mediterr Health J 2009; 15:1278-1284.

4. Fromont EG, Riche B, Rabilloud M. Toxoplasma seroprevalence in a rural population in France: detection of a household effect. BMC Infect Dis 2009, 9:76.

5. Maggi P, Volpe A, Carito V, Schinaia N, Bino S, Basho M, et al. Surveillance of toxoplasmosis in pregnant women in Albania. New Microbiol 2009; 32:89-92.

6. El-Gozamy BR, Mohamed SA, Mansour HA. Toxoplasmosis among pregnant women in Qualyobia Governorate, Egypt.J Egypt Soc Parasitol 2009; 39:389-401.

7. Inagaki ADM, Oliveira LAR, Oliveira MFB, Santos RCS, Araújo RM, Alves JAB, et al. Soroprevalência de anticorpos para toxoplasmose, rubéola, citomegalovírus, sífilis e HIV em gestantes sergipanas. Rev Soc Bras Med Trop 2009; 42:532-536.

8. Bóia MN, Carvalho-Costa FA, Sodré FC, Pinto GMT, Amendoeira MRR. Seroprevalence of Toxoplasma gondii infection among indian people living in Iauareté, São Gabriel da Cachoeira, Amazonas, Brazil. Rev Inst Med Trop 2008; 50:17-20

9. Pinheiro JW, Mota RA, Oliveira AA, Faria EB, Gondim LF, Silva AV, et al. Prevalence and risk factors associated to infection by Toxoplasma gondii in ovine in the State of Alagoas, Brazil. Parasitol Res 2009; 105:709-715.

10. Figueiró-Filho EA, Lopes AHA, Senefonte FRA, Souza Júnior VG, Botelho CA Figueiredo MS, et al. Toxoplasmose aguda: estudo da freqüência, taxa de transmissão vertical e relação entre os testes diagnósticos materno-fetais em gestantes em estado da Região Centro-Oeste do Brasil. Rev Bras Ginecol Obstet $2005 ; 27: 442-449$

11. Margonato FB, Silva AMR, Soares DA, Amaral DA, Petris AJ. Toxoplasmosis in pregnancy: diagnosis, treatment and the importance of clinical protocol. Rev Bras Saude Mater Infant 2007; 27:381-386
12. Carrellos EVM, Andrade GMQ Aguiar RALP. Evaluation of prenatal screening for toxoplasmosis in Belo Horizonte, Minas Gerais State, Brazil: a cross-sectional study of postpartum women in two maternity hospitals. Cad Saude Publica 2008; 24:391-401.

13. Montoya JG, Liesenfeld O. Toxoplasmosis. Lancet Review 2004; 363:1965-1976.

14. Mozzatto L, Procianoy RS. Incidência de toxoplasmose congênita no sul do Brasil: estudo prospectivo. Rev Inst Med Trop 2003; 45:147-151.

15. Segundo GR, Silva DA, MineoJR, Ferreira MS. A comparative study of congenital toxoplasmosis between public and private hospitals from Uberlândia, MG, Brazil Mem Inst Oswaldo Cruz 2004; 99:13-17.

16. Elsheikha HM. Congenital toxoplasmosis: Priorities for further health promotion action. Public Health Elsevier 2008; 122:335-353.

17. Lopes FMR, Mitsuka-Breganó R, Gonçalves DD, Freire RL, Karigyo CJT, Wedy GF, et al. Factors associated with seropositivity for anti-Toxoplasma gondii antibodies in pregnant women of Londrina, Paraná, Brazil. Mem Inst Oswaldo Cruz 2009; 104:378-382.

18. Innes EA. A brief history and overview of Toxoplasma gondii. Zoonoses Public Health 2010; 57:1-7.

19. Dabritz HA, Conrad PA. Cats and Toxoplasma: Implications for Public Health Zoonoses Public Health 2010; 57:34-52.

20. Santos JB. O trabalho de campo em Medicina Tropical: objetivos, planejamento e aspectos operacionais. Rev Soc Bras Med Trop 2002; 35:385-393.

21. Barros M. Clima e endemias tropicais. Estudos avançados 2006; 20:297-306.

22. Castilho-Pelloso MP, Falavigna DLM, Araújo SM, Falavigna-Guilherme AL. Monitoring of pregnant women with toxoplasmosis in public health services. Rev Soc Bras Med Trop 2005; 38:532-533.

23. Gollub EL, Leroy V, Gilbert R, Chêne G, Wallon M. Effectiveness of health education on Toxoplasma-related knowledge, behaviour, and risk of seroconversion in pregnancy. Eur J Obstet Gynecol Reprod Biol 2008; 136:137-145.

24. Jones JL, Krueger A, Schulkin J, Schantz PM. Toxoplasmosis prevention and testing in pregnancy, survey of obstetrician-gynaecologists. Zoonoses Public Health 2010; 57:27-33.

25. Instituto Brasileiro de Geografia e Estatística (IBGE) [Internet]. Ministério do Planejamento Orçamento e Gestão [updated 2010; cited 2011]. Available from: http://www.ibge.gov.br/cidadesat/topwindow.htm?1.

26. Ministério da Saúde. Database of the Public Health Care System (DATASUS) [Internet]. Indicadores Municipais de Saúde: Saneamento [updated 2000; cited 2011]. Available from: <http://portal.saude.gov.br/portal/aplicacoes/ tabfusion/tabfusion.cfm.>.

27. Logar J, Soba B, Premru-Srsen, Novak-Antolic Z. Seasonal variations in acute toxoplamosis in pregnant women in Slovenia. Clin Microbiol Infect 2005; 11: 852-855.

28. Somar, Meteorologia [Internet]. Previsão de tempo. Divinópolis MG [updated daily; cited 2008]. Available from: http://tempoagora.uol.com.br/ previsaodotempo.html/brasil/Divinopolis-MG.

29. Rea LM, Parker RA. Metodologia de Pesquisa: Planejamento à Execução $1^{\text {st }}$ ed. São Paulo: Editora Pioneira; 2000.

30. Vaughan JP, Morrow RH. Epidemiologia para municípios, manual para gerenciamento dos distritos sanitários. $3^{\text {rd }}$ ed. São Paulo: Editora Hucitec; 2002.

31. Spalding SM, Amendoeira MRR, Klein CH, Ribeiro LC. Serological screening and toxoplasmosis exposure factors among pregnant women in South of Brazil. Rev Soc Bras Med Trop 2005; 38:173-177.

32. Amendoeira MRR, Camillo-Coura LF. Uma breve revisão sobre toxoplasmose na gestação. Scientia Medica 2010; 20:113-119.

33. Varella IS, Wagner MB, Darela AC, Nunes LM, Müller RW. Seroprevalence of toxoplasmosis in pregnant women. J Pediatr 2003; 79:69-74.

34. Foulon W. Congenital toxoplasmosis: is screening desirable? Scand J Infect Dis 1992; 84:11-17.

35. Tenter AM. Toxoplasma gondii in animals used for human consumption. Mem Inst Oswaldo Cruz 2009; 104:364-369.

36. Dabritz HÁ, Miller MA, Gardner IA, Packham AE, Atwill ER, Conrad PA Risk factors for Toxoplasma gondii infection in wild rodents from central coastal Califórnia and a review of T. gondii prevalence in rodents. J Parasitol 2008; 94:675-683. 
37. Vyas A, Kim SK, Giacomini N, Boothroyd JC, Sapolsky RM. Behavioral changes induced by Toxoplasma infection of rodents are highly specific to aversion of cat odors. Proc Natl Acad Sci USA 2007; 104:6442-6447.

38. Afonso E, Lemoine M, Poulle ML, Ravat MC, Romand S, Thulliez P, et al. Spatial distribution of soil contamination by Toxoplasma gondii in relation to cat defecation behaviour in an urban area. Int J Parasitol 2008; 38:1017-1023.

39. Zou FC, Sun XT, Xie YJ, Li B, Zhao GH, Duan G. Seroprevalence of Toxoplasma gondii in pigs in southwestern China. Parasitol Int 2009; 58:306-307.

40. Millar PR, Daguer H, Vicente RT, Costa T, Sobreiro LG, Amendoeira MRR. Toxoplasma gondii: estudo soro-epidemiológico de suínos da região Sudoeste do Estado do Paraná. Pesq Vet Bras 2008; 28:15-18.

41. Belfort-Neto R, Nussenblatt V, Rizzo L, Muccioli C, Silveira C, Khan A, et al. High prevalence of unusual genotypes of Toxoplasma gondii infection in pork meat samples from Erechim, Southern Brazil. An Acad Bras Ciênc 2007; 79:111-114.

42. Millar PR, Daguer H, Vicente RT, Costa T, Carli AL, Sobreiro LG, et al. Soroprevalência de anticorpos anti-Toxoplasma gondii em trabalhadores de um matadouro de suínos e em indivíduos com outras atividades na cidade de Palmas, Paraná, Brasil. Cien Rural 2007; 37:292-295.

43. Dias RAF, Navarro IT, Ruffolo BB, Bugni FM, Castro MV, Freire RL. Toxoplasma gondii in fresh pork sausage and seroprevalence in butchers from factories in Londrina, Paraná State, Brazil. Rev Ins Med Trop 2005; 47:185-189.

44. Garcia JL, Navarro IT, Ogawa L, Marana ERM. Soroprevalência do Toxoplasma gondii em galinhas (Gallus gallus domesticus) de criações domésticas, oriundas de propriedades rurais do Norte do Paraná, Brasil. Ciênc Rural 2000; 30:123-127.

45. Silva AV, Cunha ELP, Meireles LR. Toxoplasmose em ovinos e caprinos: estudo soroepidemiológico em duas regiões do Estado de Pernambuco, Brasil. Cien Rural 2003; 33:115-119.

46. Mainardi RS, Modolo JR, Stachissini AVM, Padovani CR, Langoni H. Seroprevalence of Toxoplasma gondii in dairy goats in the São Paulo state, Brazil. Rev Soc Bras Med Trop 2003; 36:759-761.

47. Hiramoto RM, MayrbaurL-Borges M, Galisteo Jr AJ, Meireles LR, Macre MS, Andrade HF. Infectivity of cysts of the ME-49 Toxoplasma gondii strain in bovine milk and homemade cheese. Rev Saude Publica 2001; 35:113-118.

48. Reis MM, Tessaro MM, D‘Azevedo PA. Serologic profile of toxoplasmosis in pregnant women from a public hospital in Porto Alegre. Rev Bras Ginecol Obstet 2006; 28:158-164.

49. Souza CO, Tashima NT, Silva MA, Tumitan ARP. Cross-sectional study on toxoplasmosis among female students on a university course in the Presidente Prudente region, State of São Paulo. Rev Soc Bras Med Trop 2010; 43:59-61.

50. Castilho-Pelloso MP, Falavigna DLM, Falavigna-Guilherme AL. Suspected acute toxoplasmosis in pregnant women. Rev Saude Publica 2007; 41:7-34.

51. Andrade GMQ, Vasconcelos-Santos DV, Carellos EVM, Romanelli RMC, Vitor RWA, Carneiro ACAV, et al. Congenital toxoplasmosis from a chronically infected woman with reactivation of retinochoroiditis during pregnancy. J Pediatr 2010; 86:85-88. 